\title{
The right to the safe environment and the Chevron case: a new piece of the enigma concerning the relationship between the environment and the foreign investiments
}

\author{
Giulia D'Agnone*
}

\section{INTRODUCTION: THE COMPLEX RELATIONSHIP BETWEEN INVESTMENT LAW AND ENVIRONMENTAL LAW}

The relationship between foreign investment and the environment is a thorny one.

In the last 15 years, investment disputes with environmental considerations have constantly raised in number, but the relationship between foreign investments and the environment is far from clear ${ }^{1}$.

Many factors seem to contribute to this situation. Firstly, investment tribunals often ignore or are hesitant to refer to international environmental law instruments and, more often, do not know how to deal with environmental concerns $s^{2}$. In that regard, it has been noted that " $\left.\mathrm{t}\right]$ he environmental measures adopted by host States [are] thus seen as 'suspicious' (...) and in all event 'subordinated' to international (investment) law (by virtue of the rule that international law prevails over domestic law). This view (...) has sometimes been extrapolated to the assessment of genuinely environmental and even internationally-induced measures, with the unfortunate result that environmental considerations remained legally subordinated

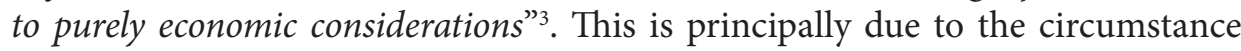
that investment treaties, both bilateral (BITs) and multilateral (MITs), do not usually contain environmental considerations. Moreover, in the absence of treaty provisions dealing with environmental issues, it is frequently debated whether measures adopted for environmental purposes constitute legitimate use of the State's police powers. Therefore, until now, environmental considerations raised in investment disputes have been treated by investment tribunals as being purely

* Post-doc in International Law. Unitelma-Sapienza Rome. 
domestic or absorbed by the broader question whether measures adopted for public policy purposes can be considered legitimate.

However, although timidly, references to the environment are more frequently appearing in recent investment treaties, both multilateral and bilateral.

First of all, it is often more frequent that Parties to investment treaties recall their commitment towards the respect and the protection of the environment in the treaties' preamble. For example, the 2004 U.S. Model BIT contains a provision which states that the parties desire to achieve the objectives contained in the treaty "in a manner consistent with the protection of health, safety and the environment". The Norway 2007 Draft Model BIT contains an analogous provisio5.

Moreover, some second-generation BITs and MITs contain substantive provisions referring to the environment. For example, Art. 11 of the before mentioned Norway Draft Model BIT, states that "the Parties recognize that it is inappropriate to encourage investment by relaxing domestic health, safety or environmental measures or core labour standards". Similarly, the recent CanadaChina BIT prescribes that " $\mathrm{t}]$ he Contracting Parties recognize that it is inappropriate to encourage investment by waving, relaxing, or otherwise derogating from domestic health, safety and environmental measures". The meaning of such clauses is quite clear: the parties of an investment agreement are under an obligation not to lower the level of protection in order to attract foreign investments and, therefore, international obligations cannot prevail over domestic environmental law ${ }^{7}$.

Besides obligations prescribing not to lower domestic standards of environmental protection, some recent investment treaties contain also clauses excluding State responsibility under the treaty for regulatory measures adopted for environmental reasons.

For instance, the already cited U.S. Model BIT contains a provision under which the Parties agree that "nothing in [the] Treaty shall be construed to prevent a party from adopting, maintaining, or enforcing any measure otherwise consistent with this Treaty that it considers appropriate to ensure that investment activity in its territory is undertaken in a manner sensitive to environmental concerns"8. As for multilateral investment treaties, Art. 18(3) of the Energy Charter Treaty prescribes that the host State is entitled to "regulate the environmental and safety aspects of [the] exploration, development and reclamation [of its energy resources] within its Area".

However, notwithstanding the growing number of environmentallyrelated disputes addressed to investment tribunals (and in particular to ICSID tribunals), and the increasing inclusion of environmental considerations in investment treaties, at the time of writing investment awards have never been based on treaties' provisions making express reference to environmental considerations ${ }^{10}$. 
This context includes a recent award on the Chevron Corporation and Texaco Petroleum Company v. Ecuador case, rendered by an arbitral tribunal instituted under the Permanent Court of Arbitration (PCA), under which a conflict between environmental law and a foreign investor's protection has arisen. The Chevron case has become very famous because of the media coverage and for the juridical saga connected to the contamination derived from the petroleum operations in the Ecuadorean Amazon put in place by the oil giant Texaco Petroleum Company. It has been noted that it is "an unprecedented case due to its importance and the severity of injustice in its origin, the extreme inequality of means amongst the parties, the simultaneous use of national and international forums, and also to the significance sentence pronounced in Ecuador and the perseverance of the victims"11.

In our perspective, this case is particularly interesting in order to test the sensibility of investment tribunals when a juxtaposition between investors protection and environmental rights comes at issue. Here the investment tribunal had to verify whether the judgments rendered by Ecuadorean Courts for environmental damages suffered by Ecuadorean citizens violated a release agreement concluded between the investor and the Quito's Government and thus amounted to a breach of the United States- Ecuador BIT. The case thus has faced the right to a safe environment counterposed to the right of protection of investments made in the host State.

In order to understand the facts of the case and the implications at issue, a step back needs to be done. Therefore, paragraph 2 will analyze the relevant steps of the juridical saga which led to the PCA Tribunal's decision. Paragraph 3 will be devoted to the analysis of the case before the Permanent Court of Arbitration in more detail. Finally, in a conclusive paragraph we draw upon this analysis to examine the implications of the case for the relationship between the environment and foreign investors protection, and to make some final remarks.

\section{THE JURIDICAL SAGA}

The case before the PCA is only a piece of a complex legal process, and it cannot be properly understood without taking into consideration previous chapters of this judicial saga.

The dispute arose from the pollution caused in the Amazon rainforest, in Ecuador, by the drilling for oil made by Texaco Petroleum Company (TexPet), an American company participating in a Consortium with Ecuador and Ecuador's state-owned oil company, Petroecuador, that explored for and produced oil under concession contracts. In 2001 TexPet was acquired by the Chevron Corporation. In 1993 a group of farmers and indigenous tribe members filed an environmental tort suit before the Federal Court of New York against Texaco, claiming for 
The right to the safe environment and the chevron case: a new piece of the enigma concerning the relationship between the environment and the foreign investiments

environmental damages caused by the oil production of the Company in the Amazon in the 1970s and 1980s (so-called Aguinda litigation).

In 2001, the case was dismissed on forum non conveniens grounds: the US Federal Court stated that it was not the appropriate forum to hear the case which, instead, had to be submitted to the Ecuadorean Courts.

Meanwhile, in 1995 TexPet concluded with Ecuador a Contract for Implementing of Environmental Remedial Work and Release from Obligations, Liability and Claims (so-called Settlement Agreement) under which Texaco would have made remedial works on the polluted territory in order to be released from liability for the polluting operations made. In 1998 Ecuador and Petroecuador concluded a Final Release Agreement with Texaco, certifying that TexPet had performed all its obligations under the 1995 Settlement Agreement and which released Texaco, its affiliates and principals from liability for environmental impact in the former Concession area. Art. 5 of the Settlement Agreement stated that "the Government and Petroecuador shall hereby release, acquit and forever discharge TexPet [...] of all the Government's and Petroecuador's claims against the Relesees for Environmental Impact arising from the Operations of the Consortium", intending "claims", under Art. 5, para. 2, of the Agreement as "any and all claims, rights to Claims, debts, aliens, common or civil law or equitable causes of actions and penalties, whether sounding in contract or tort, constitutional, statutory, or regulatory causes of action and penalties (including, but no limited to, causes of actions under Article 19-2 of the Political Constitution of the Republic of Ecuador)".

It must be recalled that at the time only Ecuador could have brought a diffuse claim under Art. 19-2 of the Ecuadorean Constitution to safeguard the right of its citizens to live in an environment free of contamination. Therefore, the Quito's Government was the sole who had the legal capacity to make and waive a diffuse claim under Art. 19-2 of the Constitution.

However, in 1999 Ecuador adopted the Environmental Management Act, a law which, amongst others, recognized that physical or juridical persons had standing to bring claims for violations of the right to a safe environment guaranteed by Art. 19-2 of the Ecuadorean Constitution.

In 2003, on the basis of the new law, a group of Ecuadorean citizens sued Chevron before the Provincial Court of Sucumbios, asking for compensation for the environmental damages caused by the oil Company (Lago Agrio litigation).

In 2011, Chevron was condemned to pay 8,6 billion US dollars, which would have become 18 if the Company would not issue a public apology ${ }^{12}$. Chevron did not apologize and appealed the Provincial Court of Sucumbios's decision. The appeal confirmed the 2011 judgment ${ }^{13}$. In November, 12, 2013, the Supreme Court of Ecuador definitely condemned Chevron to pay compensation for the environmental damages caused in Ecuador, establishing that the decision applied to the defendant and its subsidiaries, and ordered the execution of this 
judgment against Chevron Corporation in Ecuador and in countries where it may have assets ${ }^{14}$.

Because of the lack of Chevron's assets in Ecuador, the Lago Agrio plaintiffs filed claims in Canada, Brazil and Argentina. On June 5, 2013 Argentina's Supreme Court lifted a freeze on Chevron's assets, rejecting any tie to the Ecuador litigation, on the assumption that the Chevron's subsidiaries had not participated in the case against Chevron Corporation (in Ecuador) and were legally distinct units. In Brazil there are still no decisions on the matter. In Canada, after initial reluctances, in September, 4, 2015 the Canadian Supreme Court ruled that the plaintiffs were able to sue Chevron and its Canadian subsidiary.

At the same time, Chevron filed an international arbitration claim before the Permanent Court of Arbitration at the Hague. The arbitral tribunal was constituted in accordance with the BIT between United States and Ecuador of 27 August 1993 and the UNCITRAL arbitration rules ${ }^{15}$. Before that Tribunal, Chevron advanced that Ecuador breached the US- Ecuador BIT ${ }^{16}$.

In particular, the Company alleged that the Quito's government had unlawfully influenced the domestic courts' decisions, compromising the judiciary's independence and that such judgments constituted a violation of the 1995 and 1998 agreements, by which Ecuador guaranteed Texaco that it would have released it from all the claims possibly connected to the polluting activity put in place by Texaco, having them a civil, administrative or criminal nature. Therefore, Chevron assumed that Ecuador had breached the fair and equitable treatment standard under Art. II(3)(a) of the BIT and Art. II(7) under which foreign investors are recognized the right to have access to domestic courts. Chevron's objective was clearly that of avoiding execution of the Ecuadorean judgments, and it reached its aim since on February, 9, 2011 the PCA ordered Ecuador to "take all measures at its disposal to suspend or cause to be suspended the enforcement or recognition within and without Ecuador of any judgment" against Chevron ${ }^{17}$. The order was confirmed by subsequent PCA's provisional measures. However, Ecuador refused to conform to the orders and, on February, 7, 2013, the PCA tribunal recognized that it had breached its orders and reaffirmed the need for Ecuador to suspend actions aimed at executing the domestic judgments ${ }^{18}$.

As to the merit of the case, the tribunal decided to divide the decision in two tracks: Track 1 would have dealt with the question of whether the Release Agreement entered into by Texaco and the State precluded the claims in the Lago Agrio litigation. Track 2 would have focused on the denial of justice claims ${ }^{19}$.

On 17 September 2013 the PCA tribunal issued a first Partial Award on Track I which gave answer to some preliminary issues ${ }^{20}$. In particular, the PCA tribunal analyzed the scope of the 1995 Settlement Agreement, both under a subjective and an objective profile. 
As regards the subjective profile, the Arbitral tribunal had to address whether Chevron could benefit of the Agreement. The 1995 Agreement was in fact concluded between Ecuador and Texaco, which had been acquired by Chevron only later, in 2001. Ecuador sustained that Chevron could not invoke the Settlement agreement, while the oil Company insisted that it was a "Releasee" under the it, which extended to Texaco's "principales y subsidiarias".

The PCA tribunal recognized that the scope of the Agreement extended to Chevron, since "Chevron is contractually privy to the 1995 Settlement Agreement; in other words Chevron is 'party', albeit not a signatory party such as TexPet"21.

In our perspective, the relevant part of the PCA decision on Track I(A) is that relating to the objective scope of application of the Release agreement. In that regard, Chevron alleged that the Settlement Agreement released TexPet and its affiliates of any liability for all public interest or collective environmental claims and also for all individual claims for personal harm. In the decision of 17 September 2013, the tribunal retained fundamental to analyze what kind of claims were covered by the 1995 and 1998 Agreements. If consideration of this issue had led to the conclusion that the release covered all claims, there would have been no need to consider the issue whether the Lago Agrio litigation regarded individual or diffuse claims.

The 2013 decision has been further developed by the more recent Decision on Track 1B dated 12 March 2015, where the tribunal focused on whether the Lago Agrio complaint involved or not collective claims (here defined 'diffuse rights claims'), which were precluded under the Release Agreement.

\section{THE OBJECTIVE SCOPE OF APPLICATION OF THE 1995 SETTLEMENT AGREEMENT: IS THE RIGHT TO A SAFE ENVIRONMENT A DIFFUSE OR AN INDIVIDUAL RIGHT?}

Art. 5, para. 2, of the 1995 Settlement Agreement specifies that the release covered "any and all claims [...] including, but not limited to, causes of action under Article 19-2 of the Political Constitution of the Republic of Ecuador".

The PCA tribunal had to determine whether the reference made by Art. 5 of the Agreement to the right to a safe environment, as guaranteed by the Ecuadorean Constitution, impeded the Lago Agrio Claimants to have access to the Ecuadorean courts to submit claims for environmental damages against Chevron, as alleged by the oil Company.

The tribunal proceeded by first analyzing the scope of the release, with a particular look at the reference made to Art. 19 of the Ecuadorean Constitution, and then verifying whether the State could validly waive the right to ask compensation for the violation of the right to a safe environment as constitutionally guaranteed. 
As regards the scope of the release, the tribunal found that " $\mathrm{t}]$ he release does not extend to any claims made by third persons in respect of their own individual rights" and, therefore, that claims "both for personal harm claimed by an individual and also the personal claims made by identifiable Aguinda Plaintiffs in New York" were not covered by the 1995 Agreement $^{22}$. To the contrary, actions for diffuse or collective rights, defined as "indivisibile entitlement(s) that pertain to the community as a whole" were certainly covered by the Settlement Agreement, since at the time only the State was entitled to protect the right guaranteed by Art. 19 of the Constitution" 23 The tribunal recognized in fact that "under Ecuadorian law at the time when the 1995 Settlement Agreement was executed only the Respondent could bring a diffuse claim under Article 19-2 to safeguard the right of citizens to live in an environment free from contamination. At that time, no other person could bring such a claim"24.

The fact that the Environmental Management Act of 1999 recognized the right to claim under Art. 19-2 of the Constitution to individuals was considered to be of no relevance to the lawsuit.

The subsequent question to be answered and left unresolved by the provisional Award on Track I was, therefore, that regarding the nature of the rights which the Lago Agrio litigation aimed at guaranteeing.

The starting point of the analysis made by the PCA tribunal in the Decision on Track 1B of March 2015 was thus that "the questions dividing the Parties are whether the Lago Agrio Plaintiffs asserted in their Complaint only diffuse claims, brought only in a representative capacity for their communities (...); invoked only those communities indivisible rights; and did not claim any individual harm or seek any individual remedy. The Claimants answer "yes" to these questions; and the Respondent answers " $n o^{\text {'”' } 25 .}$

In order to conduce its analysis, the tribunal decided to free itself from the formal standing of the Lago Agrio plaintiffs and to consider the alleged causes of action and the substantive nature of the alleged rights invoked by the plaintiffs ${ }^{26}$.

Under this perspective, the tribunal retained that "a plaintiff's pleading in regard to the broad scope of environmental harm caused by a defendant's wrongdoing and a claim for relief in the form of remedial works did not, by themselves, affect the characterization of a claim as an individual claim under Ecuadorean law"27.

Having this in mind, the tribunal observed that the Lago Agrio complaint was a re-statement of the Aguinda litigation filed in New York, and stated that the claims under the two different proceedings were substantially the same ${ }^{28}$. The tribunal therefore concluded that, since the Lago Agrio complaint included claims substantially equivalent to the individual claims pleaded in the Aguinda complaint, it couldn't be considered as pleading exclusively or only diffuse claims.

In other terms, the tribunal did not exclude that the Lago Agrio complaint could include claims which could be qualified as diffuse claims, but the similarity 
of the Lago Agrio complaint to the Aguinda one demonstrated that also individual claims were pleaded in the first complaint ${ }^{29}$.

The award thus implied that the plaintiffs had a legitimate cause of action against Chevron, notwithstanding the Settlement Agreement and the remediation undertaken by Texaco in the past.

\section{THE RIGHT TO A SAFE ENVIRONMENT AS AN INDIVIDUAL RIGHT}

The Chevron case is a milestone in the panorama of international investment law since, to our knowledge, it is the first and only investment case which has dealt with the right to a safe environment (in the words of Art. 19 of the Ecuadorean Constitution, the "right to live in an environment free from contamination").

The weakness of the Chevron case, however, is due to the fact that the PCA tribunal did not analyze the right to a safe environment under international law.

The tribunal's grounding its decision on Ecuadorean law instead of international law has manifold explanations. In principle, there is an objective justification: the tribunal had to establish the scope of Art. 19-2 of the Ecuadorean Constitution, and therefore it was bound to apply the Ecuadorean domestic law. Moreover, it must be recalled that the international investment system is often considered a sort of self-contained regime, not willing to enter into communication with other areas of international law and in particular it "seems to be leaning toward separation of human rights and investor's rights" ${ }^{30}$. Many scholars have expressed their preoccupation on that regard ${ }^{31}$. Moreover, the relationship between investment law and the environment is, possibly, even more complex, since the placement of environmental rights in the realm of human rights presents some grey zones. As it has been observed, "Environmental rights - that is, rights understood to be related to environmental protection - are late arrivals to the body of human rights law. The drafters of the seminal human rights instrument, the 1948 Universal Declaration of Human Rights, did not include environmental rights. Nor, at the time, did the national constitutions to which the drafters looked for inspiration"32. Today, the relationship between human rights and the environment is still controversial and, therefore, international law does not constitute a clear point of reference as to the nature and scope of environmental rights for investment tribunals ${ }^{33}$.

As to the right to a safe environment, it has to be noted that, since the seventies, it has found more and more recognition within conventional systems of human rights' protection. Some of them only indirectly refer to it as a fundamental human right: for example, the European Court of Human Rights case law environmental issues have been considered in relation to the right to 
life under Art. 2 of the Convention and under Art. 8 which protects the right to a family life ${ }^{34}$. Other conventional systems expressly attribute autonomy to the right to live in a safe environment: under Art. 24 of the African Charter on Human and People's Rights and under Art. 11 of the additional Protocol to the Inter-American Convention on Human Rights, to which Ecuador is a Party, the right to a safe environment amounts to an autonomous individual right.

Coming back to the cited PCA decisions on the Chevron case, it has to be noted that, while the First Partial Award on Track I seemed to be restrictive as to the interpretation of the nature of the right to a safe environment, the 2015 Award shows more openness as to the qualification of the Lago Agrio complaint as diffuse or individual claim ${ }^{35}$. The PCA tribunal has in fact the merit of having conducted its analysis autonomously, freeing itself from formal considerations and previous decisions.

Above all, the arbitral tribunal has lost a good occasion to make reference to international law. It is undisputed that the tribunal's decision had to be founded on the Ecuadorean law. However, once more this case evidences the scarce sensibility of the investment tribunals towards environmental law.

In other terms, the tribunal could have made an effort in order to interpreted domestic environmental law in light to international law. To the contrary, no reference is made by the tribunal to international law, which could offer some guidance on the reconstruction of the right to a safe environment under Art. 19 of the Ecuadorean Constitution. For example, regarding the qualification of the right to a safe environment as a diffuse or individual right, it could have been recalled that under Art. 24 of the African Charter "all peoples shall have the right to a general satisfactory environment favourable to their development": this right, notwithstanding its diffuse nature, can be claimed both by individuals and by non-governmental organizations before the control body of the Charter ${ }^{36}$.

Therefore, international law could have represented a useful tool for the interpretation of the nature of the right to environment, even if a customary rule on that regard seems to be lacking and the international protection is principally founded on human rights conventional systems.

Conclusively, it should be recognized the courage and the "intellectual" autonomy of the tribunal as regards the reconstruction of the nature of the rights claimed by the Lago Agrio plaintiffs. However, even in the absence of an express authorization in that direction under the U.S.-Ecuador BIT, an attempt to interpret the right to a safe environment in the light of international law could have been made.

The reasons of investment tribunals' diffidence towards other branches of international law, and environmental law in particular, have already been underlined and do not need to be recalled ${ }^{37}$. There is trepidation to see whether investment tribunals will be more willing to integrate environmental considerations 
in future decisions grounded on investment treaties which authorize them to apply international environmental law by making express reference to it.

\section{NOTAS}

$1 \mathrm{~K}$. Gordon, J. Pohl, Environmental Concerns in International Investment Agreements: A survey, in OECD Working Papers on International Investment, 2011/01, OECD Publishing, p. 8.

2 A. Kulick, Global Public Interest in International Investment Law, Cambridge, 2012, p. 267.

3 J. E. Vinuales, Foreign Investment and the Environment in International Law: The Current State of Play, in K. Miles (ed.), Research Handbook on Environment and Investment Law, Cheltenham, 2016 (forthcoming).

4 United States of America 2004 Model BIT, available online at http://www.state.gov/documents/ organization/117601.pdf. See, for exemple, the bilateral investment treaty concluded on September 7, 2004, between the United States of America and the Oriental Republic of Uruguay concerning the encouragement and reciprocal protection of investments, under which the Parties "[desire] to achieve the these objectives in a manner consistent with the protection of health, safety and the environment"; see the text of the agreement at https://ustr.gov/archive/assets/World_Regions/ Americas/South_America/Uruguay_BIT/asset_upload_file582_6728.pdf.

5 Norway 2007 Draft Model BIT, available at http://www.italaw.com/sites/default/files/archive/ ita1031.pdf.

6 See Art. 18 (3) of the Agreement Between the Government of Canada and the Government of the People's Republic of China for the Promotion and Reciprocal Protection of Investments, signed on 9 September 2012 and entered into force on 1 October 2014, available at http://investmentpolicyhub. unctad.org/Download/TreatyFile/3476.

7 See also Art. VII (1) of the Agreement between the Belgium-Luxembourg Economic Union, on the one hand, and the Republic of Colombia, on the other hand, on the reciprocal promotion and protection of investments, signed on 04 February 2009 (not in force), under which "Recognising the right of each Contracting Party to establish its own levels of domestic environmental protection and environmental development policies and priorities, and to adopt or modify accordingly its environmental legislation, each Contracting Party shall strive to continue improving this legislation". The binding nature of this clause in confirmed by para. 5 of the same Article, under which "The dispute settlement mechanisms under Articles XII and XIII of this Agreement shall not apply under any obligation undertaken in accordance with this Article"; the text of the treaty is available at http:// investmentpolicyhub.unctad.org/Download/TreatyFile/342.

8 Art. 12 (2) of the U.S. 2004 Model BIT, cit..

9. The International Energy Charter Consolidated Energy Charter Treaty (with Related Documents), Last updated: 12 June 2015, available at http://www.energycharter.org/fileadmin/DocumentsMedia/ Legal/ECTC-en.pdf.

10 See J. E. Vinuales, Foreign Investment and the Environment in International Law: The Current State of Play, in K. Miles (ed.), Research Handbook on Environment and Investment Law, Cheltenham, 2016 (forthcoming). The article highlights that the majority of the 114 environmental-related cases decided concluded before investment tribunals, has been administered by the Centre for the Settlement of Investment Disputes.

11 A. Pigrau, The Texaco-Chevron Case in Ecuador: Law and Justice in the Age of Globalization, in Revista Catalana de Dret Ambiental, 2014, pp. 1-43, at p. 38. 
12 See Corte Provincial de Justicia de Sucumbios [Provincial Court of Justice of Sucumbios], 14 febrero 2011, Aguinda c. Chevron Corp., Juicio No. 2003-0002 (Ecuador), available at http:// chevrontoxico.com/assets/docs/2011-02-14-Aguinda-v-ChevronTexaco-judgement-Spanish.pdf.

13 See Sala Unica de la Corte Provincial de Justicia de Sucumbios, Aguinda c. Chevron Corp., 3 January 2012, Juicio No. 2011-0106 (Ecuador).

14 See Corte Nacional de Justicia [National Court of Justice], Aguinda c. Chevron Corp., 12 November 2013, Juicio No. 174-2012, available at http://chevrontoxico.com/assets/docs/2013-1112-final-sentence-from-cnj-de-ecuador-spanish.pdf (reversing the punitive damages but otherwise affirming the judgment).

15 Treaty between the United States of America and the Republic of Ecuador concerning the Encouragement and Reciprocal Protection of Investment signed in 27 August 1993 and entered into force on 11 May 1997, available at http://www.state.gov/documents/organization/43558.pdf.

16 See Chevron Corporation and Texaco Petroleum Corporation v. The Republic of Ecuador, PCA case No 2009-23, Claimant's Notice of Arbitration of 23 September 2009, available online at http://italaw. com/sites/default/files/case-documents/ita0155_0.pdf.

17 Chevron Corporation and Texaco Petroleum Corporation v. The Republic of Ecuador, PCA case No 2009-23, Order for Interim Measures, 9 February 2011, available at http://www.italaw.com/sites/ default/files/case-documents/ita0167.pdf.

18 Chevron Corporation and Texaco Petroleum Corporation v. The Republic of Ecuador, PCA case No 2009-23, Fourth Interim Award on Interim Measures, 7 February 2013, available at http://www. italaw.com/sites/default/files/case-documents/italaw1274.pdf.

19 Chevron Corporation and Texaco Petroleum Corporation v. The Republic of Ecuador, PCA case No 2009-23, Procedural Order No 10, 9 April 2012, available at http://www.italaw.com/sites/default/ files/case-documents/ita0913.pdf.

20 Chevron Corporation and Texaco Petroleum Corporation v. The Republic of Ecuador, PCA case No 2009-23, First Partial award on Track I, 17 September 2013, available at http://www.italaw.com/sites/ default/files/case-documents/italaw1585.pdf.

21 Chevron Corporation and Texaco Petroleum Corporation v. The Republic of Ecuador, PCA case No 2009-23, First Partial award on Track I, 17 September 2013, para. 86.

22 Chevron Corporation and Texaco Petroleum Corporation v. The Republic of Ecuador, PCA case No 2009-23, First Partial award on Track I, 17 September 2013, para. 95

23 Para. 97 of the Decision.

24 Para. 106.

25 Para. 151.

26 Para. 166

27 Para. 175.

28 Para. 180.

29 Paras 182-183.

30 M. Toral, T. Schultz, The State, a Perpetual Respondent in Investment Arbitration? Some Unorthodox Considerations, in M. Waibel, A. Kaushal, K-H Liz Chung, C. Blachin (eds), The Backlash Against Investment Arbitration: Perceptions and Reality, The Hague, 2010, p. 589. For observations on the self-contained nature of the investment system, see B. Simma, Self-contained Regimes, in Netherland Yearbook of International Law, 1985, 111-116; B. Simma, D. Pulkovski, Of Planets and the Universe: Self-Contained Regimes in International Law, in European Journal of International Law, 2006, 483-529. 
31 B. Simma, T. Kill, Harmonizing Investment Protection and International Human Rights: First Steps towards a Methodology, in C. Binder, U. Kriebaum, A. Reinisch, S. Wittich (eds.), International Investment Law for the 21st Century: Essays in Honour of Christoph Schreuer, OUP, Oxford, 2009, p. 678 ss., p. 679; on the relationship between investment law and the protection of human rights, see also P.-M. Dupuy, F. Francioni, E.-U. Petersmann (eds.), Human Rights in International Investment Arbitration, OUP, Oxford, 2009; B. Simma, Foreign Investment Arbitration: A Place for Human Rights?, in International and Comparative Law Quarterly, 2011, pp. 573-596.

32 Human Rights Council of the United Nations, Report of the Independent Expert on the Issue of Human Rights Obligations Relating to the Enjoyment of a Safe, Clean, Healthy and Sustainable Environment, John H. Knox, Preliminary Report, available at <http://www.ohchr.org/Documents/ HRBodies/HRCouncil/RegularSession/Session22/A-HRC-22-43_en.pdf>, UN doc. A/HRC/22/43 (22 December 2012), para. 7.

33 See Analytical Study on the Relationship Between Human Rights and the Environment, Report of the United Nations High Commissioner for Human Rights available at <http://www.ohchr.org/ Documents/HRBodies/HRCouncil/RegularSession/Session19/A-HRC-19-34_en.pdf>, UN doc. A/HRC/19/34 (16 December 2011), which underlines that the theoretical discussion on the relationship between human rights and the environment "engages two central issues. First, what is the nature of the relationship between human rights and the environment? Second, should the international community recognize a new human right to a healthy environment? In connection with the first issue, namely the nature of the relationship between human rights and the environment, there are three major approaches to explaining this. These approaches are capable of coexisting and do not necessarily exclude one another. The first approach postulates that the environment is a precondition to the enjoyment of human rights. This approach underscores the fact that life and human dignity are only possible where people have access to an environment with certain basic qualities. Environmental degradation, including pollution of air, water and land can affect the realization of particular rights, such as the rights to life, food and health. The second approach submits that human rights are tools to address environmental issues, both procedurally and substantively. This approach emphasizes the possibility of using human rights to achieve adequate levels of environmental protection. From a procedural perspective, rights such as access to information, participation in public affairs and access to justice are central to securing governance structures that enable society to adopt fair decision-making processes with respect to environmental issues. From a substantive perspective, this approach underscores the environmental dimensions of certain protected rights. The third approach proposes the integration of human rights and the environment under the concept of sustainable development. Accordingly, this approach underlines that societal objectives must be treated in an integrated manner and that the integration of economic, environmental and social justice issues is done with a view to the concept of sustainable development", paras 6-9. See also P. Cullet, Definition of an Environmental Right in a Human Rights Context, in Netherlands Quarterly of Human Rights, 1995, p. 5 et seq..

34 See, ex multis, A. Sironi, La tutela della persona in conseguenza di danni allambiente nella giurisprudenza della Corte europea dei diritti umani. Tra diritto al rispetto della vita privata e diritto alla vita, in Diritti umani e Diritto internazionale, 2011, p. 5 et seq.

35 About initial perplexities on the PCA's decision, see G. D'Agnone, Il riconoscimento dei diritti umani nelle decisioni arbitrali in materia di investimenti: il diritto ad un ambiente salubre nel caso Chevron, in Diritti Umani e Diritto Internazionale, 2014, p.183 et seq.

36 African Commission on Human and People's Rights, The Social and Economic Rights Action Center (SERAC) and the Center for Economic and Social Rights (CESR) v. Nigeria, communication No 155/96, 27 October 2001.

37 See para. 1 of the present contribution. 


\section{Bibliographic References}

A. Kulick, Global Public Interest in International Investment Law, Cambridge, 2012.

A. Pigrau, The Texaco-Chevron Case in Ecuador: Law and Justice in the Age of Globalization, in Revista Catalana de Dret Ambiental, 2014, pp. 1-43.

A. Sironi, La tutela della persona in conseguenza di danni all'ambiente nella giurisprudenza della Corte europea dei diritti umani. Tra diritto al rispetto della vita privata e diritto alla vita, in Diritti umani e Diritto internazionale, 2011.

African Commission on Human and People's Rights, The Social and Economic Rights Action Center (SERAC) and the Center for Economic and Social Rights (CESR) v. Nigeria, communication No 155/96, 27 October 2001.

Agreement between the Belgium-Luxembourg Economic Union, on the one hand, and the Republic of Colombia, on the other hand, on the reciprocal promotion and protection of investments, signed on 04 February 2009, the text of the treaty is available at http://investmentpolicyhub.unctad.org/Download/TreatyFile/342.

Agreement Between the Government of Canada and the Government of the People's Republic of China for the Promotion and Reciprocal Protection of Investments, signed on 9 September 2012 and entered into force on 1 October 2014, available at http:// investmentpolicyhub.unctad.org/Download/TreatyFile/3476.

Analytical Study on the Relationship Between Human Rights and the Environment, Report of the United Nations High Commissioner for Human Rights available at <http://www. ohchr.org/Documents/HRBodies/HRCouncil/RegularSession/Session19/A-HRC-19-34_ en.pdf>, UN doc. A/HRC/19/34 (16 December 2011).

B. Simma, Self-contained Regimes, in Netherland Yearbook of International Law, 1985, 111-116; B. Simma, D. Pulkovski, Of Planets and the Universe: Self-Contained Regimes in International Law, in European Journal of International Law, 2006, 483-529.

B. Simma, T. Kill, Harmonizing Investment Protection and International Human Rights: First Steps towards a Methodology, in C. Binder, U. Kriebaum, A. Reinisch, S. Wittich (eds.), International Investment Law for the 21st Century: Essays in Honour of Christoph Schreuer, OUP, Oxford, 2009.

Chevron Corporation and Texaco Petroleum Corporation v. The Republic of Ecuador, PCA case No 2009-23, Claimant's Notice of Arbitration of 23 September 2009, available online at http://italaw.com/sites/default/files/case-documents/ita0155_0.pdf.

Chevron Corporation and Texaco Petroleum Corporation v. The Republic of Ecuador, PCA case No 2009-23, Order for Interim Measures, 9 February 2011, available at http://www. italaw.com/sites/default/files/case-documents/ita0167.pdf. 
The right to the safe environment and the chevron case: a new piece of the enigma concerning the relationship between the environment and the foreign investiments

Chevron Corporation and Texaco Petroleum Corporation v. The Republic of Ecuador, PCA case No 2009-23, Fourth Interim Award on Interim Measures, 7 February 2013, available at http://www.italaw.com/sites/default/files/case-documents/italaw1274.pdf.

Chevron Corporation and Texaco Petroleum Corporation v. The Republic of Ecuador, PCA case No 2009-23, Procedural Order No 10, 9 April 2012, available at http://www.italaw. $\mathrm{com} /$ sites/default/files/case-documents/ita0913.pdf.

Chevron Corporation and Texaco Petroleum Corporation v. The Republic of Ecuador, PCA case No 2009-23, First Partial award on Track I, 17 September 2013, available at http:// www.italaw.com/sites/default/files/case-documents/italaw1585.pdf.

Corte Nacional de Justicia [National Court of Justice], Aguinda c. Chevron Corp., 12 November 2013, Juicio No. 174-2012, available at http://chevrontoxico.com/assets/ docs/2013-11-12-final-sentence-from-cnj-de-ecuador-spanish.pdf .

Corte Provincial de Justicia de Sucumbios [Provincial Court of Justice of Sucumbios], 14 febrero 2011, Aguinda c. Chevron Corp., Juicio No. 2003-0002 (Ecuador), available at http://chevrontoxico.com/assets/docs/2011-02-14-Aguinda-v-ChevronTexacojudgement-Spanish.pdf.

D’Agnone, Il riconoscimento dei diritti umani nelle decisioni arbitrali in materia di investimenti: il diritto ad un ambiente salubre nel caso Chevron, in Diritti Umani e Diritto Internazionale, 2014, p.183 et seq.

Human Rights Council of the United Nations, Report of the Independent Expert on the Issue of Human Rights Obligations Relating to the Enjoyment of a Safe, Clean, Healthy and Sustainable Environment, John H. Knox, Preliminary Report, available at <http://www. ohchr.org/Documents/HRBodies/HRCouncil/RegularSession/Session22/A-HRC-22-43_ en.pdf>, UN doc. A/HRC/22/43 (22 December 2012).

J. E. Vinuales, Foreign Investment and the Environment in International Law: The Current State of Play, in K. Miles (ed.), Research Handbook on Environment and Investment Law, Cheltenham, 2016 (forthcoming).

K. Gordon, J. Pohl, Environmental Concerns in International Investment Agreements: A survey, in OECD Working Papers on International Investment, 2011/01, OECD Publishing.

M. Toral, T. Schultz, The State, a Perpetual Respondent in Investment Arbitration? Some Unorthodox Considerations, in M. Waibel, A. Kaushal, K-H Liz Chung, C. Blachin (eds), The Backlash Against Investment Arbitration: Perceptions and Reality, The Hague, 2010.

Norway 2007 Draft Model BIT, available at http://www.italaw.com/sites/default/files/ archive/ita1031.pdf.

P. Cullet, Definition of an Environmental Right in a Human Rights Context, in Netherlands Quarterly of Human Rights, 1995.. 
P.-M. Dupuy, F. Francioni, E.-U. Petersmann (eds.), Human Rights in International Investment Arbitration, OUP, Oxford, 2009; B. Simma, Foreign Investment Arbitration: A Place for Human Rights?, in International and Comparative Law Quarterly, 2011, pp. 573-596.

Sala Unica de la Corte Provincial de Justicia de Sucumbios, Aguinda c. Chevron Corp., 3 January 2012, Juicio No. 2011-0106 (Ecuador).

The International Energy Charter Consolidated Energy Charter Treaty (with Related Documents), Last updated: 12 June 2015, available at http://www.energycharter.org/ fileadmin/DocumentsMedia/Legal/ECTC-en.pdf.

Treaty between the United States of America and the Republic of Ecuador concerning the Encouragement and Reciprocal Protection of Investment signed in 27 August 1993 and entered into force on 11 May 1997, available at http://www.state.gov/documents/ organization/43558.pdf.

United States of America 2004 Model BIT, available online at http://www.state.gov/ documents/organization/117601.pdf. 


\begin{abstract}
This work aim to analyze the relationship between the foreign investiments and the Environmental Law. For it, it is questioned about the role of the International Environmental Law, having in account that the Treaties of Investiment, both bilateral and multilateral, have only recently started to embrace the environmental issue, generally in its preambles. In that sense, it is examined the factors that contribute to this situation, as far as the role of the States in the execution of environmental policies affected by clauses contained in such treaties and of the Tribunals of Investments to whom disputes are directed.
\end{abstract}

Keywords: Chevron Case. International Environmental Law. Treaties of Investment. Tribunals of Investment. 


\title{
O DIREITO AO AMBIENTE SEGURO E O CASO DA CHEVRON: UMA NOVA PEÇA DO ENIGMA SOBRE A RELAÇÃO ENTRE O MEIO AMBIENTE E OS INVESTIMENTOS ESTRANGEIROS
}

\begin{abstract}
Resumo
O presente trabalho destina-se a analisar a relação entre investimento estrangeiro e direito ambiental. Para tanto, indaga acerca do papel do direito ambiental internacional, tendo-se em conta que os tratados de investimentos, tanto bilaterais quanto multilaterais, só recentemente começam a contemplar a questão ambiental, geralmente em seus preâmbulos. Examinam-se, deste modo, os fatores que contribuem para esta situação, bem como o papel dos Estados na execução das políticas ambientais afetadas por cláusulas constantes de tais tratados e dos tribunais de investimento a quem as disputas são dirigidas.
\end{abstract}

Palavras-chave: Caso Chevron. Direito ambiental internacional. Tratados de investimento. Tribunais de investimento.

Recebido em: março de 2018.

Aprovado em: agosto de 2018. 